\title{
Development of Worksheet Mathematics Student Based on Inquiry to Improve Critical Thinking Ability
}

\author{
$1{ }^{\text {st }}$ Ranny Putri Yoma \\ Mathematics and Science Faculty \\ Universitas Negeri Padang \\ Padang, Indonesia \\ rannypeye2212@gmail.com
}

\author{
$2^{\text {nd }}$ Armiati \\ Mathematics and Science Faculty \\ Universitas Negeri Padang \\ Padang, Indonesia \\ armiati_math_UNP@yahoo.co.id
}

\begin{abstract}
This research originated from students' low critical thinking skills. The low ability of critical thinking mathematically is due to the unavailability of the Student Worksheet that can support the improvement of students' critical thinking skills. The learning process has not been able to help students to develop and develop their knowledge in finding their own mathematical principles / procedures. The purpose of this study was to produce an inquiry-based Student Worksheet to improve the mathematical critical thinking skills of grade VIII SMP / MTs students. This development research carried out using the Plomp development model. The Plomp development model consists of three phases, namely the initial investigation phase, the prototype development phase, and the assessment phase. Based on the development that has been carried out, an inquiry-based mathematics student worksheet was obtained for the eighth grade of SMP / MTs that met the criteria of preliminary research.
\end{abstract}

\section{Keywords - Critical thinking, Inquiry, Student Worksheet}

\section{INTRODUCTION}

The ability to think critically mathematically is a very important ability in learning mathematics, given that critical thinking prepares students to face various challenges that will arise in their lives, career, level of obligations and their personal responsibilities. However, students' critical thinking skills at this time are not yet in line with the expectations of the curriculum where critical thinking is the main focus in mathematics learning.

For an educator, the success of the students will open the door to a brilliant career. For citizens, mathematics will support the right decision making. For a country, mathematics will prepare its citizens to compete and compete in the field of economics and technology [1].

Based on observations and interviews, many students who cannot restate the material appropriately, classify objects according to certain traits according to their concepts and provide examples and not examples of concepts and apply concepts in solving problems.

Based on interviews with mathematics educators it is also known that educators have attempted to apply learning approaches / methods / models that can activate students in the learning process. However, the learning objectives are still not achieved because of the low mathematical critical thinking skills of students as explained previously. One of the reasons is because of the lack of learning resources used by students that can help to build their own knowledge and be active in learning activities so that critical thinking increases.

One of the sources used is the Student Worksheet. The Student Worksheet used is less attractive and does not meet the learning needs. The material in the Student Worksheet is immediately explained and has not exposed students to problems that stimulate students' reasoning. This causes students to be more likely to memorize than to understand the material. The Student Worksheet has not provided the opportunity for students to re-invent (find / create) mathematics through practice. The Student Worksheet should be used to stimulate students' reasoning. In the Student Worksheet, there are activities / questions that can build students' knowledge in understanding the material. Therefore, it is necessary to develop a Student Worksheet that can help improve students' reasoning.

In addition, the Student Worksheet used is not fully capable of being a means for students to develop students' critical thinking skills because the Student Worksheet used by educators is sold on the market. The Student Worksheet used has not seen any guidelines in the form of questions that guide students to work to solve problems so that students' critical thinking skills can be awakened. The existing Student Worksheet only contains material in general, examples and exercises that are in accordance with the examples so that students do not understand the different questions in the sample questions given. Such presentation causes students to tend to always follow the way they are when working on questions.

Efforts to overcome this problem required the development of inquiry-based mathematics student worksheets to improve critical thinking skills. The inquiry is an approach to learning by directing students to be able to find out for themselves about a concept that exists in the material. Kunandar also stated "learning with an inquiry approach is to encourage students to learn through their own active involvement with concepts and principles for themselves" [2] This inquiry-based Student Worksheet prioritizes active and effective involvement of students to orient, formulate problems, formulate hypotheses, collect data, test hypotheses and formulate conclusions so that learning activities run in an interesting, fun, and challenging way for students to think. The Student Worksheet that uses an inquiry approach seeks to instill the 
basics of scientific thinking in students, so that in the learning process students learn more themselves in finding concepts.

Improving worksheet based on Inquiry will help students to solve the problems and it will increase their critical thinking ability. The inquiry is expected to train the activeness of students to find, apply and deepen mathematics material so as to create conducive learning conditions and improve students' critical thinking mathematically.

Inquiry-based Student Worksheet designed to improve students' critical thinking skills because inquiry learning knowledge is built into the minds of students. This inquirybased Student Worksheet is one tool that can be used by mathematics educators to help students understand a mathematical concept and at the same time improve students' critical thinking skills. That ability will equip students in facing everyday problems. A good Student Worksheet in learning mathematics will provide the widest possible opportunity for students to develop their ability to solve a problem.

The process of preparing the Student Worksheet needs to be guided by the steps that have been set. These steps as stated by the Ministry of National Education [4] are as follows:

\section{Curriculum analysis}

Curriculum analysis is intended to determine which materials require teaching materials Student Learning Worksheets Usually in determining the material analyzed by looking at the subject matter and learning experience of the material to be taught, then the competencies that must be possessed by students.

\section{Compile a Map of the Need for Student Worksheets}

The needs map of the Student Worksheet is very necessary to know the number of Student Worksheets that must be written and the sequence or sequence of the Student Worksheet can also be seen. This sequence of Student Worksheets is very necessary for determining writing priorities. Beginning with curriculum analysis and analysis of learning resources.

\section{Determine the Titles of the Student Worksheet}

The title of the Student Worksheet is determined on the basis of Basic Competencies, subject matter or learning experience contained in the curriculum. One Basic Competency can be used as the title of a Student Worksheet if the competency is not too large, while the amount of Basic Competency can be detected, among others, by the way, if it is described into the subject matter to get a maximum of 4 subject matter, then the competency can be used as a Sheet title Student Work.

\section{Writing of Student Worksheets}

Writing a Student Worksheet can be done with the following steps: a. Basic Competency Formulation in the Student Worksheet is directly derived from Core Competencies

\section{b. Determine the Assessment Tool}

Assessment is carried out on the work process and the work of students.

\section{c. Compile Material}

Student Worksheet Material is very dependent on the Basic Competencies to be achieved. Student Worksheet material can be in the form of supporting information, which is a general description or scope of the substance to be studied.

\section{d. Structure of Student Worksheets}

The structure of the Student Worksheet, in general, is as follows: title, learning instructions (student instructions), competencies to be achieved, supporting information, assignments and work steps, assessment.

So it can be concluded that, with the existence of the Student Worksheet, the educator and students are very helpful in the implementation of learning. And students can be directed to find the concept of learning material independently or in groups. In addition, students can practice more by working on available exercises.

\section{METHODS}

This type of research is research and development. In this research and development, the product developed was an inquiry-based Student Worksheet to improve critical thinking skills in the eighth grade of SMPN. The development model used in this study is the Plomp model developed by Tjeerd Plomp. The Plomp development model consists of three stages, namely preliminary research, prototyping making is the preparation stage which consists of needs analysis, student analysis, curriculum analysis, and concept analysis, prototyping stage which is the process of designing and developing learning tools in stages by using formative evaluation to improve and improve the prototype developed, assessment phase in the form of a semi summative evaluation to conclude whether the final prototype or product is in accordance with the desired and submit recommendations for product development.

\section{RESULTS AND DISCUSSION}

\section{Preliminary Research}

This initial investigation phase is to establish and define the conditions needed in the development of a Mathematical Student Worksheet. This stage is carried out by analyzing the objectives within the limits of the material that the students have developed. There are four main steps in this stage, namely:

\section{1).Needs Analysis}

At this stage of needs analysis, information is obtained that there needs to be an update on the Student Worksheet to achieve the learning objectives of mathematics. The results of the Student Worksheet analysis were obtained information that the existing Student Worksheet is enough 
to help students to practice working on math problems both at school and at home, but the Student Worksheet has not been able to optimize students' critical thinking skills in mathematics, because there are no activities or questions to optimize knowledge independently so that learning is more meaningful and students do not easily forget the material being studied.

Examples of Student Worksheets used in schools:

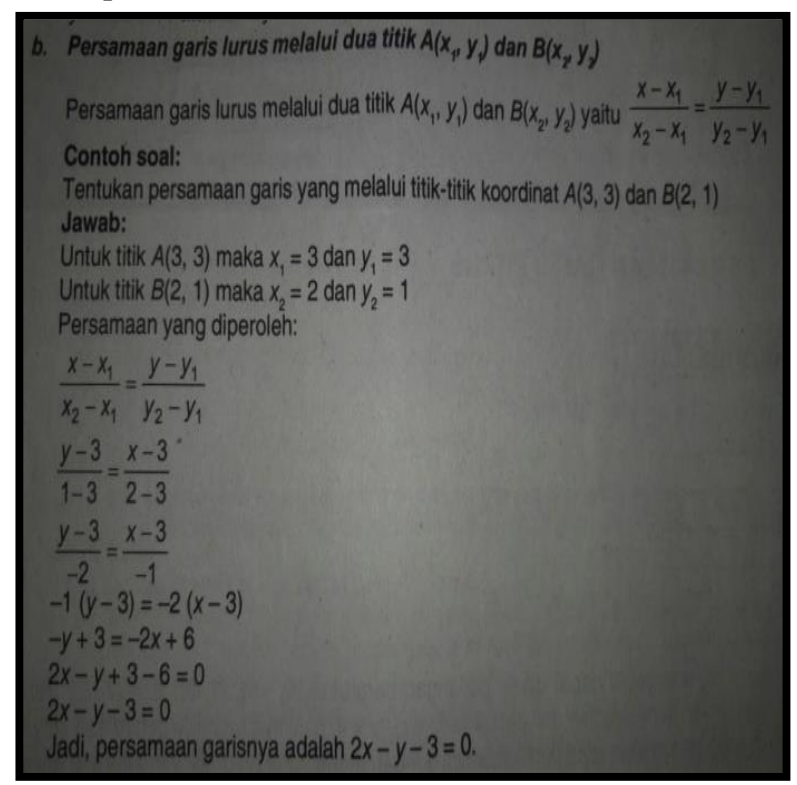

Figure 1. Example of a Student Worksheet

Design of inquiry-based Student Worksheet. As shown in the picture below:

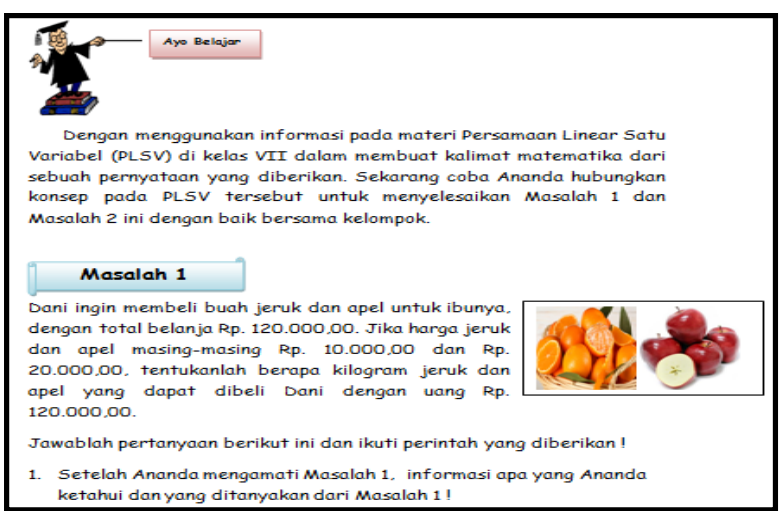

2. Setelah ananda mengetahui dari permasalahan 1, buatlah tabel yang menunjukan hubungan banyak jeruk (dalam kilogram), banyak apel (dalam kilogram), dan total belanja (dalam rupiah), sekarang tentukanlah kemungkinan-kemungkinan berapa kilogram jeruk dan apel yang dapat dibeli Dani dengan uang yang dimilikinya?

3. Berdasarkan dari jawaban yang telah anda peroleh agar mempermudah jawaban tersebut bagaimana bentuk aljabar yang mewakili jawaban yang di peroleh dari pernyataan 2 pada masalah 1 ? Jelaskan!

4. Apakah Ananda yakin dengan jawaban yang anda peroleh? Coba
buktikan!
5. Setelah Ananda menjawab permasalahan 1. diskusikan hasil yang
kamu peroleh dengan teman sekelompokmu!




\section{Masalah 2}

Dalam rangka memperingati hari kemerdekaan Republik Indonesia yang ke-72, seluruh peserta didik tingkat 5MP/MTs se Kec.Batang Anai mengadakan pawai dengan tema pakaian daerah. Salah satu kelos SMPS PROF DR HAMKA mengikuti pawai tersebut. Kelos tersebut ingin menggunkan jasa sewa pakaian daerah. Wali kelos mencari dan mengamati beberapa brosur dari jasa sewa pakaian yang berada di daerah tempat tinggalnya. Josa sewa pakaian tersebut samasama menawarkan pakaian daerah dengan kualitos baik yang tampak seperti dibawah ini:

Sewa 1: Baju daerah Rp. $120.000,00$

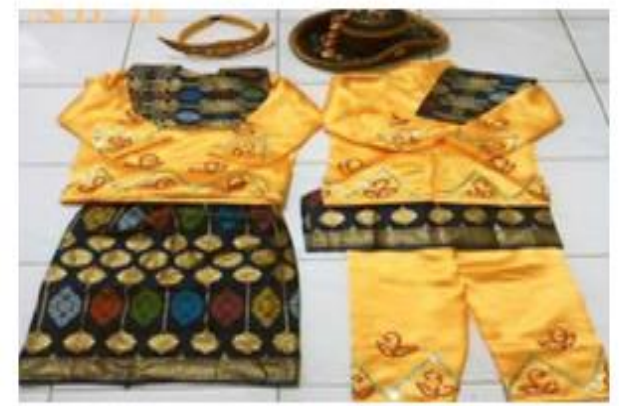

Gambar 1

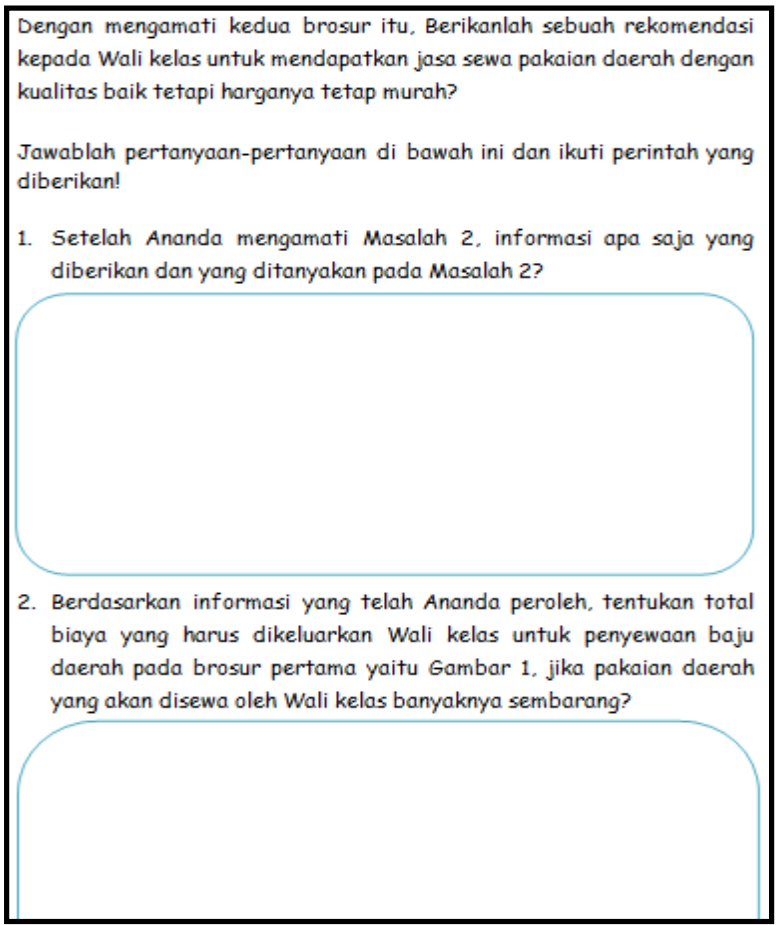

3. Untuk melihat perbedaan dari kedua brosur, tentukan juga total biaya yang nantinya dikeluarkan oleh Wali kelas, jika Wali kelas menyewa pakaian daerah yang juga secara sembarang pada brosur kedua yaitu Gambar 2?

4. Sekarang buatlah dengan kalimat Ananda sendiri bagaimana cara menentukan biaya total yang harus dikeluarkan oleh Wali kelos pada masing-masing brosur?

4. Sekarang buatlah dengan kalimat Ananda sendiri bagaimana cara menentukan biaya total yang harus dikeluarkan oleh Wali kelos pada masing-masing brosur?

5. Berdasarkan kalimat yang telah Ananda tulis dalam menentukan total biaya yang akan dikeluarkan oleh Wali kelas pada kedua brosur, untuk mempermudahnya jawaban dari banyaknya kemungkinan, jika Wali kelos belum mengetahui banyaknya pakaian daerah yang akan disewa, maka sekarang buatlah bentuk aljabar yang menurut Ananda dapat mewakili Mosalah 2? jeloskan! 


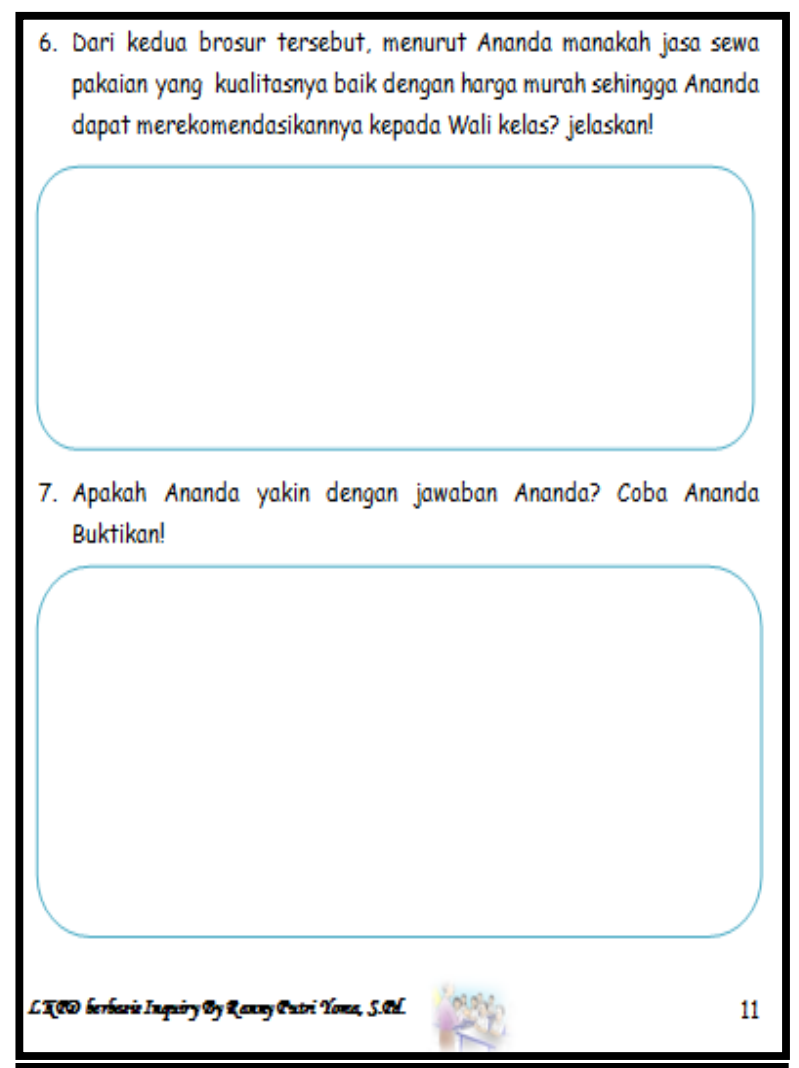

8. Setelah Ananda menjawab permasalahan 2, diskusikan hosil yang kamu peroleh dengan teman sekelompokmu!

Berdasarkan Masalah 1 dan Masalah 2, Ananda dapat memahami konsep persamaan linear dua variabel (PLDV) yaitu dalam kegiatan menentukkan banyak kemungkinan dari pembelian 2 jenis makanan dan membandingkan 2 jenis brosur serta Ananda juga telah merubah suatu permasalahan ke dalam bentuk aljabar atau model kalimat matematika dari PLDV. Sekarang simpulkanlah dengan bahasa Ananda sendiri mengenai apa itu PLOV dan bagaimana bentuk umum dari bentuk aljabar PLDV.

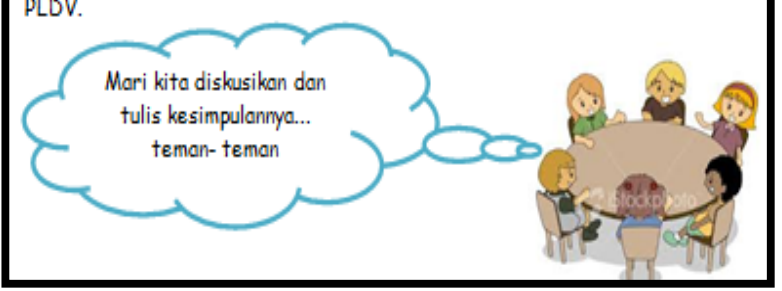

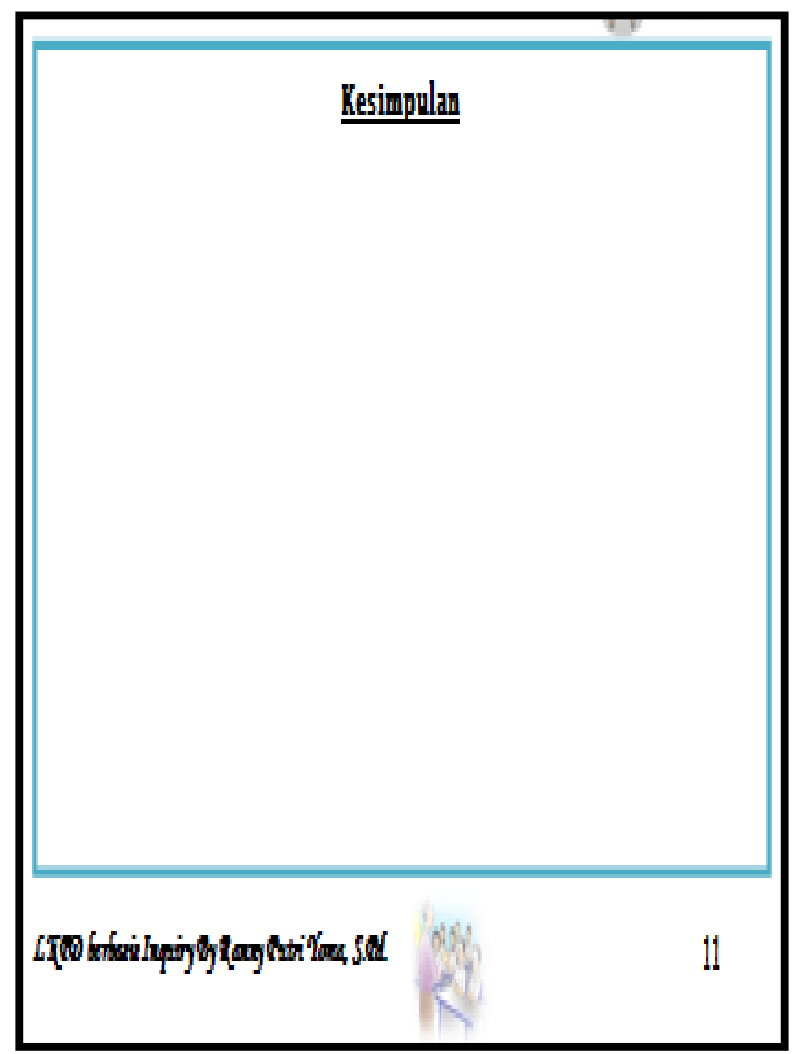

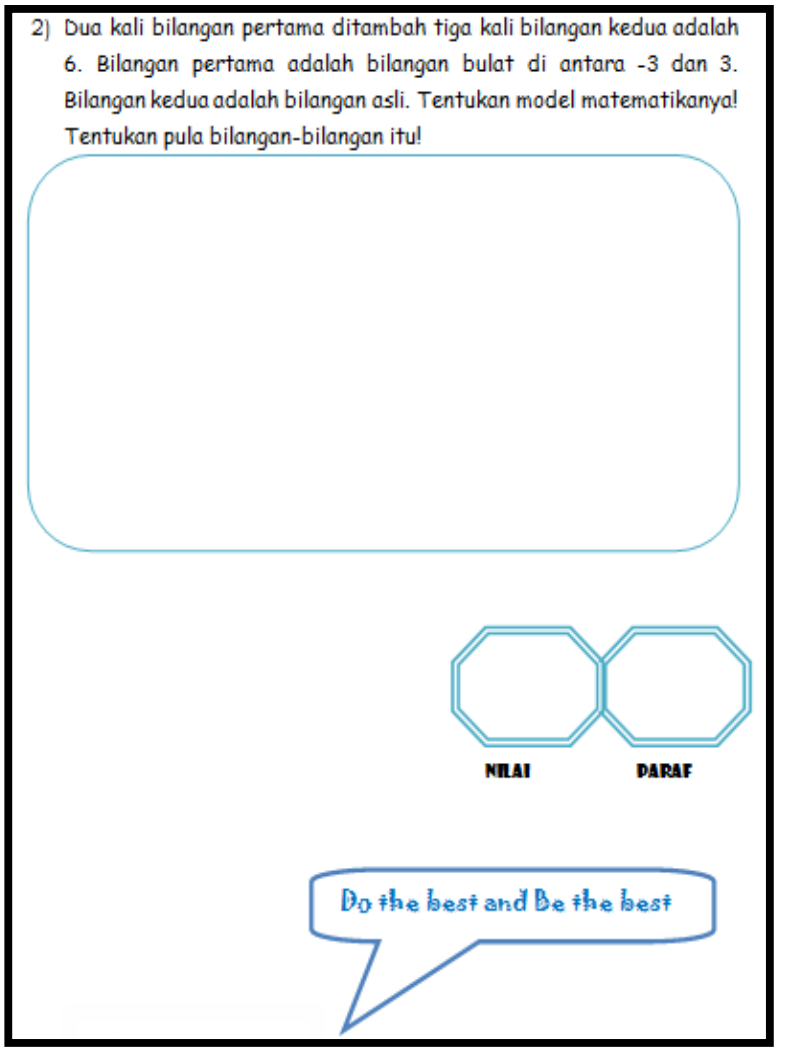




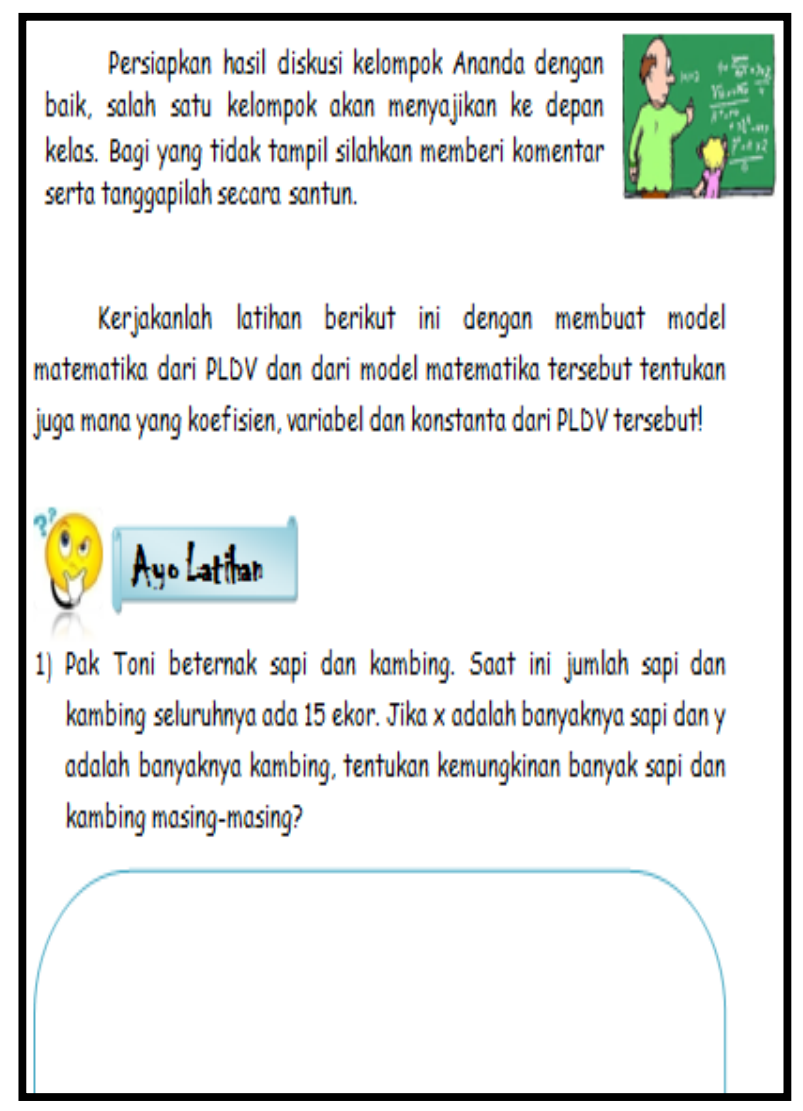

\section{2).Student Analysis}

Analysis of students is a study of the needs of students in accordance with the design of the development of inquiry-based Student Worksheet. The average students who sit in class VIII have the age of 13-15 years. According to Piaget's cognitive development theory (in Budiningsih) [5] they are in the formal operational stage (formal operational period) with the main characteristics of development already able to think abstractly, logically, draw conclusions, interpret and develop hypotheses, so that it can be concluded that students have been able doing critical thinking activities because their cognitive development has reached a high level of thinking. Students in this class have a formal level that is expected to be directed to systematic and complex thinking.

\section{3).Curriculum Analysis}

Curriculum analysis aims to analyze the curriculum on two supporting aspects namely Core Competence and Basic Competence. At this stage, a review of the 2013 curriculum was conducted for the eyes of mathematics students in the eighth grade of SMP / MTs. This analysis is carried out for material coverage, learning objectives, and strategies were chosen as the basis for developing an inquiry-based Student Worksheet.

At this stage, an examination of the 2013 curriculum for the eighth-grade mathematics subjects in the odd semester was conducted. This analysis is a guideline in developing inquiry-based Student Worksheets. Analysis of the basic competencies of this material is the development of indicators using inquiry-based learning to organize the material and determine the learning objectives to be achieved at each meeting. All indicators designed have been adjusted to Basic Competence and refer to indicators of critical thinking.

\section{4) .Concept Analysis}

This concept analysis is done by identifying the main concepts that will be taught and compiling them systematically in accordance with the order of presentation. Concept analysis also aims to identify the facts, concepts, principles, and procedures that must be mastered by students. This concept analysis is done so that the students' activity sheets that are developed contain appropriate and appropriate concepts.

\section{REFERENCES}

[1] Permendikbud Nomor 58 Tahun 2014 tentang - 2014. Jakarta : Kemendikbud

[2] Kunandar, Guru profesional implementasi kurikulum Tingkat Satuan Pendidikan dan sukses dalam sertifikasi guru, Jakarta : PT. Raya Grafindo Persada, 2007.

[3] Trianto, Pengantar Penelitian Pendidikan Bagi Pengembangan Profesi Pendidikan dan Tenaga Kependidikan, Jakarta: Kencana, 2011.

[4] Depdiknas, Pedoman Memilih Menyusun Bahan Ajar dan Teks Mata Pelajaran, Jakarta: Depdiknas: 2008.

[5] Budiningsih. Asri,Belajar dan Pembelajaran, Jakarta: Rineka Cipta, 2012. 